\title{
LEGAL EFFECTS ON NATIONAL ECONOMY
}

\author{
Yusep Mulyana \\ Universities Pasundan, Indonesia \\ yusep.mulyana@unpas.ac.id
}

\begin{abstract}
Legislation plays an important role in the economic development of a nation, but that the law can play a role in providing legal certainty for economic operators, the government as policy makers in the field of law. Determination of investment legislation in an effort to create a climate of investment, beginning with the presence of the Capital Market Law normatively accommodates the various interests of foreign investors. For example, there is the provision and maintenance of non-discrimination given to local entrepreneurs or the arena of domestic market share, investment protection and guarantees against nationalization and export risk threats, as well as the guarantee of the right to transfer profits or dividends. And the right to carry out legal settlement through international arbitration. Law in economic development, there are five elements that must be developed in the economic development of the nation, namely stability, prediction, justice, education, and in particular the development of law graduates (special development ability of the prosecutor) and the law should also have the ability to give an exact picture in situations or a future relationship conducted in the present. Both have procedural capability. Legislation that directly or indirectly impact on the economy and the legal system must provide a balance in awareness efforts to implement economic development. This is where the law becomes a very important factor in relation to the legal protection afforded by a country for investment activities. As revealed by Erman Rajagukguk that the main factor for the law can play a role in economic development is whether the law is able to create "stability", "predictability" and "fairness". The first two are the prerequisites for any economic system functioning. Included in the stability function (stability) is a potential law to balance and accommodate competing interests. The legal system and legal regulations to provide protection will create predictability, fairness and efficiency for investors to invest their capital. Act Investment in efforts to create an investment climate begins with Act Capital Markets normatively accommodate the interests of foreign investors and the legal concept as the basis for economic development, namely predictability, the ability procedural codification goals, education, the balance, the definition and clarity of status and accommodation
\end{abstract}

\section{Keywords: Influence, Law, National Economy}

\section{Introduction}

Indonesia as a developing country has extraordinary potential to become the most developed and prosperous country in the world.

We can see the potential of the abundant natural resources in thousands of islands scattered across the archipelago. The great potential of these will be able to contribute more to the world if it is supported by human resources in developing reliable and innovative ideas that can make Indonesia a country that is recognized worldwide. Of course many systems need to be improved, one of which is the legal system.

Discourse on improving the legal system is no longer new in Indonesia. According to the record submitted by the Indonesian Forum Foundation in early 2007 that in order to achieve the Vision Indonesia in 2030 there are some requirements that must be met, namely tax reform, reform of the bureaucracy, reform of the legal system, good governance is supported by all components of the nation, and most importantly, there is a leader who has the vision and strong leadership.

Placement reform of the legal system as a prerequisite to achieving the Vision Indonesia 2030 is the thought and the right strategic move, because without prioritizing law as one of the main supporters to achieve the prosperity of the nation, the will of the efforts made in vain as it did in the era of new order. 
According to research Burg about the law and economic development, there are five elements that must be developed in the economic development of the nation, namely stability, prediction, justice, education, and specifically the development of law graduates (special development capabilities of attorney).

Here stability 'functions to accommodate and avoid competing interests. Prediction is the need to be able to predict the provisions relating to the economy of a country.

Burg outlook is in line with JD Nyhart, which also promote the concept of law as the basis for economic development.

Mrs. Hart suggested that there are six concepts in the science of law which have influence on the development of economic life.

The first begins with the concept of predictability in which the law should have the ability to provide a precise figure in a future situation or relationship that is done in the present. Both procedural capabilities. Procedural procedural law is required to be able to maximize the function of the material law in resolving disputes.

The third is the codification of the goal. Legislation can be viewed as a codification of the goals and intentions desired by the country. For example in the economic field, we will be able to meet these objectives as defined in the legislation that directly or indirectly have an impact on the economy. Fourth, the balancing factor. The legal system must provide a balance in the consciousness of attempts to carry out economic development.

Accommodation fifth, here the legal system governing the relationship between the individual both materially and formally provide opportunities disturbed balance to adapt to new environments as a result of these changes. And sixth, the definition and clarity of status. In addition to the legal function that provides predictability, may be added that the legal function also provides firmness regarding the status of persons and goods within the community.
Globalization is characterized by openness and freedom in various areas of life that produces changes in various aspects of life is going very fast. Through globalization and information disclosure, open economic activity to the point where business transactions can be done anywhere and anytime. Forms of electronic transactions are not a new thing anymore, wherein the electronic transaction, the agreement will take place electronically.

In line with this development, forms of business activities in the era of globalization continues to grow rapidly following the development of other forms of business activity in the world. Even many foreign economic institutions enter and flourish in Indonesia, which is sometimes not suitable for Indonesia. As forms of legal institutions developed in the Anglo-Saxon legal tradition with a common law legal system where the differences become obstacles in its application.

With advances in technology, forms of electronic transactions has been developed, which are forms of involvement or the legal relationship which is much discussed as an online contract, the agreement or the legal relationship which is done electronically by combining network (networking) of a computer based information system with communication-based systems network and telecommunications services.

So in this case has given rise to a resolution of trade and electronic business transactions covering how the sale, purchase products, services and business transactions themselves. Through e-commerce transactions, the transactions have been guided by the paper is accompanied with an authorized signature as transaction documents into electronic transactions with electronic documents without signatures is proof of the validity of the transaction.

The Changes that occur due to business needs do so resulted in the import or acquisition of a foreign law that is generally carried unanimously, which means that it is applied as it is without any significant changes or adjustments. So often in practice cause problems and obstacles. Most of the foreign legal provisions taken over really came from what is practiced in countries that adhere to the Anglo-Saxon legal system 
such as the UK and the US, although Indonesia itself adheres to the Continental European legal systems.

So what happens is that the existing company law transplant Anglo-Saxon legal institutions into the body of the Continental European law. In this case the body is in the form of Anglo-Saxon law while his feet are still grounded in Continental European law, which in many cases are forced transplantation. As a result, new business law firm that is not regulated in the Indonesian legal system has evolved, so the implementation of which often cause conflicts or disputes, which in this case is known as a business dispute.

Legal / Business Company is an important legal institution given the fairly rapid business growth and also considering the disputes that occur that require law enforcement agencies definite and clear for the organization. Therefore, business law and corporate law are necessary in practice, especially legal effect on the national economy.

The problem of this research is the Effect of National Economy Act?

\section{Method}

\section{Accompanying Law Globalization}

Economic Globalization

Indonesia also experienced as experienced by most other developing countries, although the government did not explicitly state that Indonesia as one of the "adherents" of the market economic system, in fact Indonesia has begun to implement this economic system to guide its economy, because Indonesia is involved in trade organizations both regional and multilateral worlds such as GATT, AFTA, WTO, and others.

The reorientation of the economic system towards a market economy has actually also been carried out since the launch of the deregulation policy in 1983. Where the deregulation policy aims to strengthen the functioning of the market economy in Indonesia. In this case the Government began to direct the allocation of all resources and prices in accordance with the wishes and desires of the market. Furthermore, according to Normin $\mathrm{S}$.
Pakpahan, for the three decades since Pelita $\mathrm{I}$, in fact Indonesia has conducted a market economy.

Then what happened in most developing countries also happened in Indonesia, where the market economy system adopted by Indonesia could not work optimally as expected before, this was caused by many internal constraints that existed in Indonesia itself, which then made the economy the market can't work. The market economy system which is expected to make Indonesia's economy healthy is the opposite. The market economic system instead promotes monopolistic practices and unfair business competition in the market, and causes markets to become increasingly inefficient.

Referring to the view of neoclassical flow of the economy considers the market to run perfectly without cost (without cost) because the buyer (consumer) has perfect information and the seller (producer) competes with each other resulting in low costs. But in reality the fact is the opposite, where information, competition, contract systems, and the buying and selling process can be very asymmetrical.

Damage to the market economy, also caused by the fact that previously there were no rules or institutions in the market before, which will direct the behavior of economic actors in the market, so they will not behave deviant in the market, by trying to avoid fair competition among economic agents, with the intention so they can exploit the consumer surplus as much as possible and get the maximum profit.

One non-market institution that is expected to protect the market from being trapped in endless failures is through strong economic legal institutions. The absence of strong economic legal institutions is thought to be the cause of a market economy not working as expected, which is creating prosperity for many people.

A strong economic law institution when referring to Prof.'s opinion Erman Rajagukguk is an economic legal institution which is more or less capable of creating "stability", "certainty" and "justice". 
Then the first two are prerequisites for the economic system to function. Included in the function of stability (stability) is the legal potential to balance and accommodate competing interests.

The need for a legal function can be predicted as a result of the steps taken which are very important for the country where most people first enter economic relations outside the traditional social environment. Fairness aspects, such as equal treatment and standard behavior patterns of the Government are needed to maintain market mechanisms and prevent excessive bureaucracy. And no less important, if you quote Prof. Charles Himawan that the existence of a reliable judicial body (reliable judiciary) is also very decisive for the legal process of business disputes faced by economic actors.

Institutional economic law that existed at the time Indonesia began implementing the market economy system, if it refers to the opinion of Prof. Hikmahanto Juwana, is no longer in accordance with existing developments.

Therefore it is necessary to make adjustments to existing economic legal institutions to support market economy work in Indonesia. And the adjustment of economic legal institutions is done in one way through the process of legal transplants from the United States and Europe to Indonesian economic legal institutions.

This legal transplantation process is expected to make economic legal institutions in Indonesia more modern, and can better accommodate current needs related to economic activities that cannot yet be met by economic legal institutions in Indonesia. So if it refers to Lawrence Friedman's opinion about the three elements of the legal system namely the structure, substance and culture of law when it is associated with economic legal institutions. Then the structure is a frame or frame, a part that survives, a part that gives a kind of shape and boundary to the whole.

In Indonesia, for example, if we talk about the structure of the legal system, it includes the structure of law enforcement agencies, such as

\section{Legal Effects on the National Economy}

The pattern of fast-paced economic development now, has led to the formation of the achievement of equal distribution of people's welfare is the main goal. To achieve this goal, it takes the role of law that brings influence to arrange the new life order. In subsequent developments, attention is no longer directed at the surrounding cultivation of the law, but rather associated with social changes.

The law is no longer seen as a recorder of habits that have shaped in the fields of community life, but it is also hoped that the law can be an appropriate expression of the new forces that demand the formation of people's welfare. As a result, almost all aspects of our lives meet the existence of legal regulations.

On the one hand, the law is concerned with the results that will be obtained through its regulation, and therefore must understand about the intricacies of the problem to be regulated. Whereas on the other hand, the law must also be aware that factors and forces outside the law will also have an effect on the law and the work process. So in preparing legal policies, it is necessary to consider, among others, psychological factors, sociological factors and geographical location.

Investment is one of the drivers of the process of strengthening the country's economy; therefore in the context of its economic policies some countries are trying hard to increase their investment. One of the expected ways to increase investment is through foreign investment. Investors invited to enter a country are expected to be able to bring fresh funds directly in the hope that the incoming capital can move the wheels of companies / industries which in turn can drive a country's economy.

In the era of globalization, the inclusion of investment in a developing country, especially Indonesia, is a very significant role in spurring economic development. Because in developing countries the need for large development capital has always been a major problem in economic development.

So that among developing countries the concern for investors is not only the rich 
natural resources, but the most important is how the investment law in the country can provide legal certainty and business certainty.

With the strengthening of the current economic globalization that has led to interdependence and integration in the fields of finance, production and trade, it has had an impact on Indonesia's economic management. This impact is felt even more after the flow of economic globalization increasingly developed the principle of trade liberalization which has been pursued jointly by countries in the world in the form of regional economic cooperation, such as the North American Free Trade (NAFTA), Single European Market ( SEM), European Free Trade Agreement (EFTA), AustralianNew Zealand Closer Economic Relations and Trade Agreement (ANCERTA), ASEAN Free Trade Area (AFTA), Asia Pacific Economic Cooperation (APEC) and World Trade Organization (WTO).

This is where the law is a very important factor in relation to the legal protection given by a country for investment activities. As revealed by Erman Rajagukguk, that the main factor for the law to be able to play a role in economic development is whether the law is able to create "stability", "predictability" and "fairness". The first two are prerequisites for any economic system to function. Included in the function of stability (stability) is the potential for the law to balance and accommodate competing interests.

The need for a legal function to be predictable as a result of the steps taken is especially important for a country where most people first enter economic relations beyond the traditional social environment.

Fairness aspects, such as equal treatment and standard behavior patterns of the Government are necessary to maintain market mechanisms and prevent excessive bureaucracy. So that through the legal system and legal regulations that can provide protection, will create predictability, fairness and efficiency for investors to invest their capital.

The investment climate in Indonesia has been relatively fast developing since the 1967 PMA Law and the 1968 PMD Law were enacted. This is because there are several incentive arrangements, which include protection and investment guarantees, employment for foreign workers, and incentives in the field of taxation. And the political and security situation at that time was relatively more stable which encouraged investment so that it experienced a significant increase. Even in the early $70 \mathrm{~s}$ until the end of the $80 \mathrm{~s}$, Japan made massive investments in Indonesia.

The growth of investment (direct investment) continued until 1996 along with various liberalism policies in the field of finance and trade issued by the Government. However, the investment growth experienced a decline which ended with the economic crisis at the end of 1997 which became a multidensional crisis that affected political stability.

According to Bismar Nasution, for Indonesia whose open economy will be affected by the principles of the global economy and the principle of trade liberalization. Because the Indonesian economy will deal with the economies of other countries / the economies of Indonesia's trading partners such as export-import; investment, both direct and indirect investment; and lending and borrowing. This economic influence is a challenge for the formulation of national policies, the world economy and economic actors.

Various studies show that Indonesia's investment climate is worse than China, Thailand, Vietnam and other ASEAN countries. The investment climate can be defined 'as all policies, institutions and the environment, both ongoing and expected to occur in the future, which can affect the rate of return and risk of an investment'.

The state of the Indonesian economy became very worse when Indonesia was hit by a crisis at the end of 1997 which had very broad consequences. The economic crisis then became a crisis of public and business confidence in the political elite and the New Order economic elite which eventually undermined the economy and business administration, so many investors fled to other countries. The economic crisis has at least provided lessons for the Indonesian people and forced Indonesia to make economic, political, social and legal changes. 
The reform era is expected to be the cornerstone of transformation and legal reform towards a new system that is more just, reliable and sustainable, in particular the arrangement of investment law in creating a business climate that is more conducive to investment.

The structuring of investment law in an effort to create the investment climate has begun with the presence of the Capital Market Law, which normatively accommodates the interests of foreign investors. For example there are provisions and non-discriminatory treatment, given to local or domestic entrepreneurs in the arena of market share, investment protection and guarantees against the threat of the risk of nationalization and exportation, and the existence of guarantees in the right to transfer profits or dividends, as well as the right to carry out legal settlement through international arbitration.

study of law and development, there are 5 (five) elements that must be developed so as not to hamper the economy, namely "stability", "prediction", "fairness", "education" (education)), and "the special development of law graduates" (the special development abilities of the lawyer).

Burg's argues that the first and second elements above are requirements for the functioning of the economic system. Here "stability" functions to accommodate and avoid competing interests. While "prediction" is the need to be able to predict the provisions relating to a country's economy.

As Erman Radjagukguk argues, investment law as part of economic law must have a stability function, namely how the legal potential can balance and accommodate competing interests in society. So that investment law can accommodate the interests of foreign capital and at the same time can also protect local entrepreneurs or small businesses. In this connection, investment will be greatly influenced by political stability.

Investors who want to come to a country are strongly influenced by political stability. Political elite conflict or community conflict will affect the investment climate. Foreign investors will come and develop their business if the country concerned is awakened by a process of political stability and a constitutional democratic process.

Second, the need for an investment legal function to be able to predict (predictability), is to require that the law brings certainty. Investors will come to a country if he believes the law will protect investments made. Legal certainty will provide guarantees to investors to obtain economic oppurtunity so that investment can provide economic benefits for investors. The existence of legal certainty is also one of the main factors to create a conducive climate for investors, because in investing in addition to being subject to investment law provisions, also other related provisions and cannot be released as a consideration for investors to invest their capital.

With so many regulations that govern investment and which are related to investment it sometimes creates confusion or uncertainty which law applies.

If it is associated with the existence of the law with the community, then the need for legal authority in order to be obeyed and as a guideline in carrying out relations with one another especially in business traffic requires the existence of legal certainty in force. This was also stated by Sentosa Sembiring, if the importance of law is related to investment, investors need legal certainty in running their business. That is, for investors there needs to be a measure that becomes a handle in carrying out its investment activities. These measures are called rules made by those who have the authority to do so. The rule applies to all parties.

Third, aspects of justice (fairness), such as, equal treatment for all people or parties before the law, equal treatment of all people and the existence of standard patterns of government behavior, by many experts emphasized as a condition for the course of maintaining market mechanisms and preventing bureaucracy that exaggerated. In relation to the aspect of justice here, the accountability factor by carrying out constitutional reforms and improving the judicial and legal system is an important requirement in order to attract investors.

If this is not done it will ultimately result in weak law enforcement and the absence of 
regulations, especially in the field of investment that is able to provide a sense of security, comfort for investors and the lack of friendliness of these laws to investors, especially foreign investors.

In other words, the existing legislative instruments are felt to be inadequate in accommodating the interests of investors in investing. As revealed by Dorojatun Kuntjoro Jakti while serving as Coordinating Minister for the Economy stated that the small amount of investment entering Indonesia was due to the persistence of obstacles regarding the taxation system, customs, bureaucratic procedures, regional administration, and labor issues.

In accordance with Burg's opinion above, JD Mrs. Hart also put forward the concept of law as the basis for economic development, namely predictability, procedural capability, codification of goals, education, balance, definition and clarity of status and accommodation. With reference to the legal approach in economic development above, the law must contain the following elements: First, the law must be able to make predictions, namely whether the law can provide guarantees and legal certainty for actors in predicting what activities carried out for economic development projections.

Second, the law has procedural capability in dispute resolution. For example in regulating tribunal justice (court or administrative tribunal), dispute resolution outside the court (alternative dispute resolution) and the appointment of conciliation arbitration (conciliation) and institutions that function equally in dispute resolution. Third, the codification of the law (codification of goals) by lawmakers aimed at developing the country.

Fourth, after the law has validity, in order to have the ability it must be made education (education) and then socialized. Fifth, the law can play a role in creating a balance. Because this is related to economic development initiatives. Sixth, the law has a role in determining the definition and clear status (definition and clarity of status).

In this case the law must provide a clear definition and status regarding everything from people. Seventh, the law must be able to accommodate (accommodation) the balance, definition and clear status for the interests of individuals or groups in society. Finally, no less important and must be in the legal approach as the basis for development is the element of stability (stability) as described earlier.

Three main things that investors and entrepreneurs want: system simplification and licensing, reduction in overlapping levies, and transparency in licensing fees. Overlapping central and regional regulations, which not only impede the flow of goods and services but also create an unhealthy business climate, need to be eliminated. Priority needs to be given to deregulation and coordination of various regional and central regulations.

The experience of China attracting foreign capital needs to be examined whether it is interesting to try. In China, for licensing it is sufficient to contact the Foreign Investment Office. For a minimum investment of US \$ 30 million, investment applications must get permission from the center. But below that amount, just contact the Foreign Investment Office in the area. The maximum investment approval time is 3 days. If more than 3 days there is no notification from this office, the investment application will automatically be deemed accepted.

Based on the description above, it is clear to the Indonesian people, that one of the efforts to revive the national economy is how to create a conducive business climate. By structuring economic law, especially investment law, it is expected to encourage investment in Indonesia, both domestic and foreign investment. The policies formulated must be able to make Indonesia compete with countries in ASEAN in particular, in attracting foreign investment.

According to Dhaniswara K. Harjono, in relation to this matter and in order to improve and create a favorable investment climate and in line with the direction and policies of national development, the steps that have been taken are:

1. Simplify the licensing and approval processes and procedures for investment;

2. Widely opening fields that were originally closed or restricted to foreign investment; 
3. Providing various incentives, both tax and non-tax;

4. Developing areas for investment with various facilities offered;

5. Perfect various legal products by issuing new laws and regulations that better guarantee a healthy investment climate;

6. Improve the process of law enforcement and dispute resolution that is effective and fair;

7. Improve the duties, functions and authority of related agencies to be able to provide better services;

8. Open the possibility of greater foreign share ownership.

\section{Result and Discussion}

The government should provide the most basic facilities for services aimed at investors, including investment licensing, immigration, customs, taxation and regional defense. Maintaining labor climate conditions that support business activities in a sustainable manner.

There is legal certainty over regulations at the central and regional levels as well as producing legal products related to investment activities so as not to burden additional burdens on business production costs.

\section{Conclusion}

As for some of the conclusions I took, some of them are:

1. The law plays an important role in the economic development of a nation but in order for the law to be able to play its role in providing legal certainty to economic actors, the government as policy maker is responsible for making law authoritative by responding and following up on improving the legal system by collaborating with theories stated by experts so that in the future the law is expected to be able to play its role as a guiding factor, counseling, and creating a conducive climate in the economic field.

2. The arrangement of investment law in an effort to create an investment climate, has begun with the presence of the Capital Market Law which normatively accommodates the various interests of foreign investors. For example there are provisions and non-discriminatory treatment, given to local or domestic entrepreneurs in the arena of market share, investment protection and guarantees against the threat of the risk of nationalization and exportation, and the existence of guarantees in the right to transfer profits or dividends, as well as the right to carry out legal settlement through international arbitration.

\section{References}

Achmad Ali, 2002. "Deterioration of Law in Indonesia: Causes and Solutions," Jakarta: Ghalia Indonesia Publisher.

Bismar Nasution, Legal Reform in the Framework of the Era of Economic Globalization, Presented at "Discussion of Legal Development in the Framework of the Era of Economic Globalization," at the USU Faculty of Law, Medan, September 25, 1999.

Charles Himawan. 2003."Economic Recovery Needs" Reliable Judiciary ". In the book Law as Commander in Chief. Cet.1. Jakarta: Kompas Book Publisher.

Dhaniswara K. Harjono, Investment Law, PT. Rajagrafindo Persada, Jakarta, 2007

Dorojatun Kuntjoro Jakti, "Minimal Investment Due to Five Things," Bisnis Indonesia, June 13, 2002.

Erman Rajagukguk, "Indonesian Economic Law Strengthens National Unity, Encourages Economic Growth and Expands Social Welfare," Paper presented at the VIII National Law Development Workshop and Workshop organized by the National Legal Development Agency, Ministry of Justice and Human Rights, Denpasar, 14July 18, 2003.

Investment Law in Indonesia, Faculty of Law, Al-Azhar University of Indonesia, Cet. I-Jakarta, 2007. , the Role of Law in Development in the Era of Globalization: The Implications for Legal Education in Indonesia. Inauguration speech by Professor of FH-UI, Jakarta: January 4, 1997.

Gunarto Suhardi, Role of Law in Economic Development. Atma Jaya University, Yogyakarta, 2002.

Hikmahanto Juwana, "The Political Law of the Law on Economics in Indonesia." 2nd lecture material Legal Aspects in 
Economic Policy Batch XV PD Masters Program Public Policy Planning-FEUI. , Economic Law and International Law. Jakarta: Lentera Hati, 2002. https://www.kai.or.id/berita/13838/peranhukum-in-pembangunan-ekonomibangsa.html/ accessed June 22020

JD Ny. Hart, "The Role of Law in Economic Development," in Erman Rajagukguk, The Role of Law in Economic Development, Volume 2, University of Indonesia, Jakarta, 1995

Kartadjoemena, HS Substance of the GATT / WTO Agreement and Dispute Resolution Mechanism. Jakarta: UI Press, 2000.

Leonard J. Theberge, "Law and Economic Development," Journal of International Law and Policy Vol. 9, 1990

Normin S. Pakpahan, "Main Principles of Framework for Reference to the Draft of Bill on Competition." In Journal of Business Law Volume 4, 1998.
"ELIPS Seminar Summary Invention of Competition Law: A Comparative Analytic Service." In the journal Business Law Volume 4, 1998.

Oakley, Peter \& amp; David Marsden, Approaches to Participation in Rural Development, ILO, Geneva. 1994.

R. Shyam Khemani project director, "A framework for the design and implementation of competition law and policy," World Bank, OECD, 1998.

Satjipto Rahardjo, "Liberalism, Capitalism, and Indonesian Law," in the book "Other Sides of Law in Indonesia," Kompas Book Publisher, Jakarta, 2003.

Sentosa Sembiring, Investment Law, Bandung, CV. Nuance of Aulia, 2007

T. Mulya Lubis, ed. The Role of Law in the Economy in Developing Countries. Obor Indonesia Foundation, Jakarta, 1996.

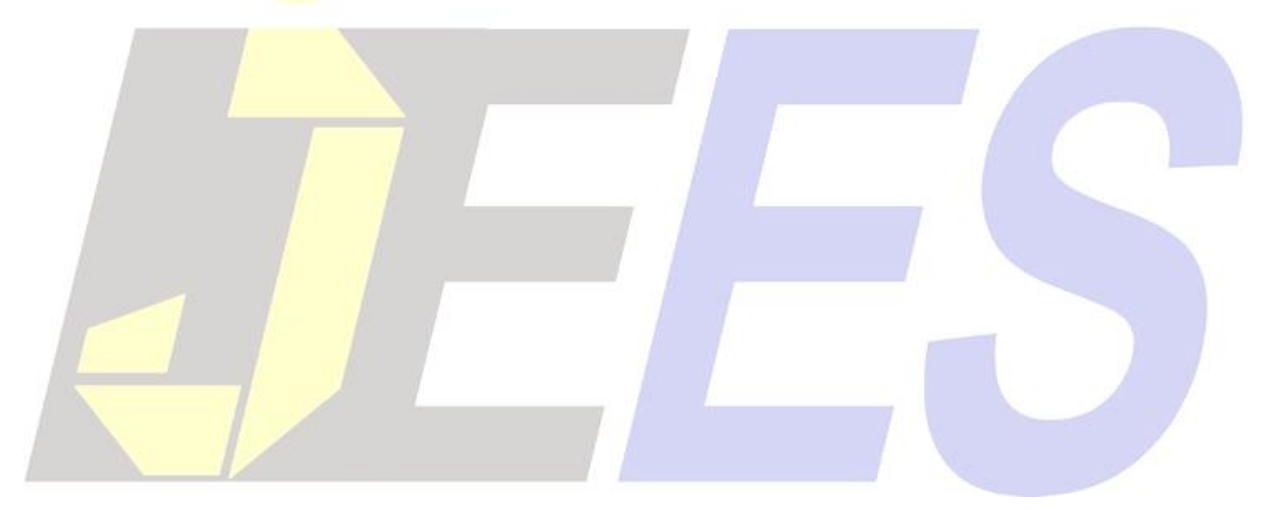

